\title{
Research Rehabilitation of an Incised Stream Using Plant Materials: the
Dominance of Geomorphic Processes
}

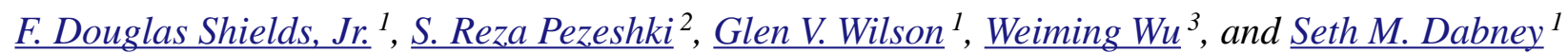

\begin{abstract}
The restoration of potentially species-rich stream ecosystems in physically unstable environments is challenging, and few attempts have been evaluated scientifically. Restoration approaches that involve living and dead native vegetation are attractive economically and from an ecological standpoint. A 2-km reach of an incised, sand-bed stream in northern Mississippi was treated with large wood structures and willow plantings to trigger responses that would result in increasing similarity with a lightly degraded reference stream. Experimental approaches for stream bank and gully stabilization were also examined. Although the project was initially successful in producing improved aquatic habitat, after $4 \mathrm{yr}$ it had failed to effectively address issues related to flashy watershed hydrology and physical instability manifest by erosion and sedimentation. The success of ecosystem rehabilitation was thus governed by landscape-scale hydrological and geomorphological processes.
\end{abstract}

Key Words: biotechnical stabilization; erosion; fish community structure; gullies; large wood; physical aquatic habitat; stream restoration; willows

\section{INTRODUCTION}

Degraded freshwater aquatic ecosystems, particularly those impacted by agricultural production, are being targeted increasingly for ecological rehabilitation. Many streams in agricultural landscapes have been straightened or otherwise modified to the point that they no longer provide ecological services such as habitat diversity, flood mitigation, or nutrient retention. Extreme channel incision often follows these modifications (Darby and Simon 1999). Accordingly, stream corridor restoration, or perhaps more accurately, rehabilitation (Shields et al. 2003), is drawing increasing levels of interest and investment (Palmer et al. 2005). Only a small minority of stream restoration projects is evaluated, and few indeed are monitored for a wide range of variables for many years or offer detailed accounts of failure (Hobbs 2005, Palmer et al. 2005, 2007). Structural approaches for arresting channel incision and attendant erosion are available but costly, with reported expenditures of US $\$ 400 \mathrm{~m}^{-1}$ of channel length or US\$750 ha-1 of watershed area (Shields et al. 2004), which is well beyond the means of most rural riparian landowners in the southeastern United
States. Approaches based on native vegetation, both living and dead, might be more harmonious with ecological processes and thus more sustainable and cost effective. However, the success of such measures is dependent on landscape-scale geomorphic processes that create, destroy, and control plant habitats and large wood budgets.

\section{STUDY SITE}

Little Topashaw Creek, Chickasaw County, Mississippi, drains approximately $37 \mathrm{~km}^{2}$ and lies within the $800-\mathrm{km}^{2}$ Yalobusha River watershed in north-central Mississippi (Fig. 1). Repeated straightening most channels within the watershed during the period from 1913 to 1967 promoted widespread channel incision that was slightly retarded by outcrops of cohesive materials in channel beds (Hanson and Simon 2001, Simon and Thomas 2002). Most channels were incised by 1 to $6 \mathrm{~m}$, creating highly unstable banks that generated major inputs of sediment from mass failures and riparian gullies and triggered accelerated large wood inputs (Downs and Simon 2001). Knickpoint 
(sharp changes in slope, often marked by waterfalls) migration rates of 0.6 to $16 \mathrm{~m} / \mathrm{yr}$ were observed. Sediments and large wood generated by channel instability collected and formed a $3 \mathrm{~km}$ long channel plug in the Yalobusha River mainstem approximately $25 \mathrm{~km}$ downstream from the mouth of Little Topashaw Creek that triggered up to $5 \mathrm{~m}$ of aggradation (Simon and Thomas 2002). Backwater from the debris plug did not extend to our study site. A channel was dredged through the plug in 2003, 3 yr after our rehabilitation project was constructed.

At the outset of our study, the contributing watershed of Little Topashaw Creek had cultivated valley floors and forested hillslopes with maximum relief of approximately $65 \mathrm{~m}$; only approximately $12 \%$ of the area was in cultivation or used as pasture. Adjacent to the study reach, 75 ha of fields with silty loam to sandy loam soils were planted in cotton (Gossypium hirsutum L.) and corn (Zea mays L.). The floodplain stratigraphy was characterized by dispersive silt and clay soils over layers of sand overlying consolidated cohesive material. Most soils that were exposed in eroding banks had silt or sandy loam over alternating layers of sand and clay loam (Wilson et al. 2007). Bed materials were composed primarily of medium sand, but cohesive materials occurred as massive outcrops and as gravel-sized aggregates. Channels upstream and downstream from the study reach were straightened in approximately 1913, and downstream reaches were again channelized in 1967 . However, the study reach was a remnant of the natural stream channel. In 1999, the average reach sinuosity was 2.1, average channel width was $33 \mathrm{~m}$, average depth was $3.6 \mathrm{~m}$, and average slope was 0.0025 .

Precipitation averaged $1477 \mathrm{~mm} / \mathrm{yr}$ during the study period, and the overall regime was characterized by wet periods interspersed by moderately severe droughts (Fig. 2). Water reached the stream channel from the upstream reach, from concentrated overland flows, from flows through lateral ditches, and as groundwater emerging from the channel banks. Water likely also reached the stream as groundwater emerging from the sand bed. However, the interaction between surface and subsurface flows was slight, consistent with reports by other workers who studied small, sand bed streams (Stofleth et al. 2008).

The most striking characteristics of the study reach were its flashy hydrology and physical instability.
Streamflow reflected the upstream channel straightening, incision, and the absence of floodplain storage (Shankman and Pugh 1992, Shields and Cooper 1994, Doyle and Shields 1998). During our 6-yr study, only one overbank flow was observed, and it occurred prior to the initiation of stream gaging. The estimated $2-y r$ discharge (i.e., the magnitude of discharge equaled or exceeded, on average, once every two years) is $74 \mathrm{~m}^{3} / \mathrm{s}$ with a standard error of $35 \%$ (Ries and Crouse 2002). An observed discharge of $55 \mathrm{~m}^{3} / \mathrm{s}$ only reached midbank levels. High flow events tended to be extremely brief $(<30 \mathrm{~h})$ and frequent, with maximum depths of approximately $3 \mathrm{~m}$ and occasional velocities as great as $3 \mathrm{~m} / \mathrm{s}$; base flows were generally $<0.10 \mathrm{~m}^{3} / \mathrm{s}$.

Similar to flow, stream water quality displayed extreme variability. Temperature extremes ranged from near 0 to $\sim 30^{\circ} \mathrm{C}$, with the greatest diurnal variation occurring during extremely shallow low flows. Pollutant concentrations tended to spike during runoff events (Smith et al. 2006). Peaks in herbicide and insecticide concentrations coincided closely with runoff following spring applications. Peak concentrations of DDT (dichloro-diphenyltrichloroethane) and dieldrin and their metabolites (pp'DDD [dichlorodiphenyldichloroethane], pp'DDE [dichlorodiphenyldichloroethylene]) were associated with high flows that carried elevated levels of suspended sediment. Pesticide concentrations generally declined during the fall and did not exceed trace levels during winter. Total phosphorus, total nitrogen, and chlorophyll-a concentrations commonly exceeded proposed criteria for total maximum daily load (Lizotte et al. 2006).

Inputs of sediment to the stream were sporadic because of the episodic nature of bank retreat, headcut advancement, and gully development (Fig. $3)$. Channel incision triggered the formation of approximately 30 riparian gullies along the study reach because concentrated flows of runoff or floodwaters that returned to the channel following an overbank event produced rapid erosion of the high banks (Dabney et al. 2004). Preliminary estimates suggest that gully erosion produced sediment at a rate equivalent to $42 \%$ of the sediment yield for the entire watershed containing the study site (Wilson et al. unpublished data). High banks were also sites for piping as a result of seepage erosion because subsurface flows as great as $0.9 \mathrm{~m}^{3} /$ $\mathrm{s}$ with sediment concentrations as great as 660,000 $\mathrm{mg} / \mathrm{L}$ emerged from individual pipes during rainy 
Fig. 1. Location of Little Topashaw Creek watershed in the Yalobusha River watershed, Mississippi. The rehabilitated reach is indicated by the hatched area.

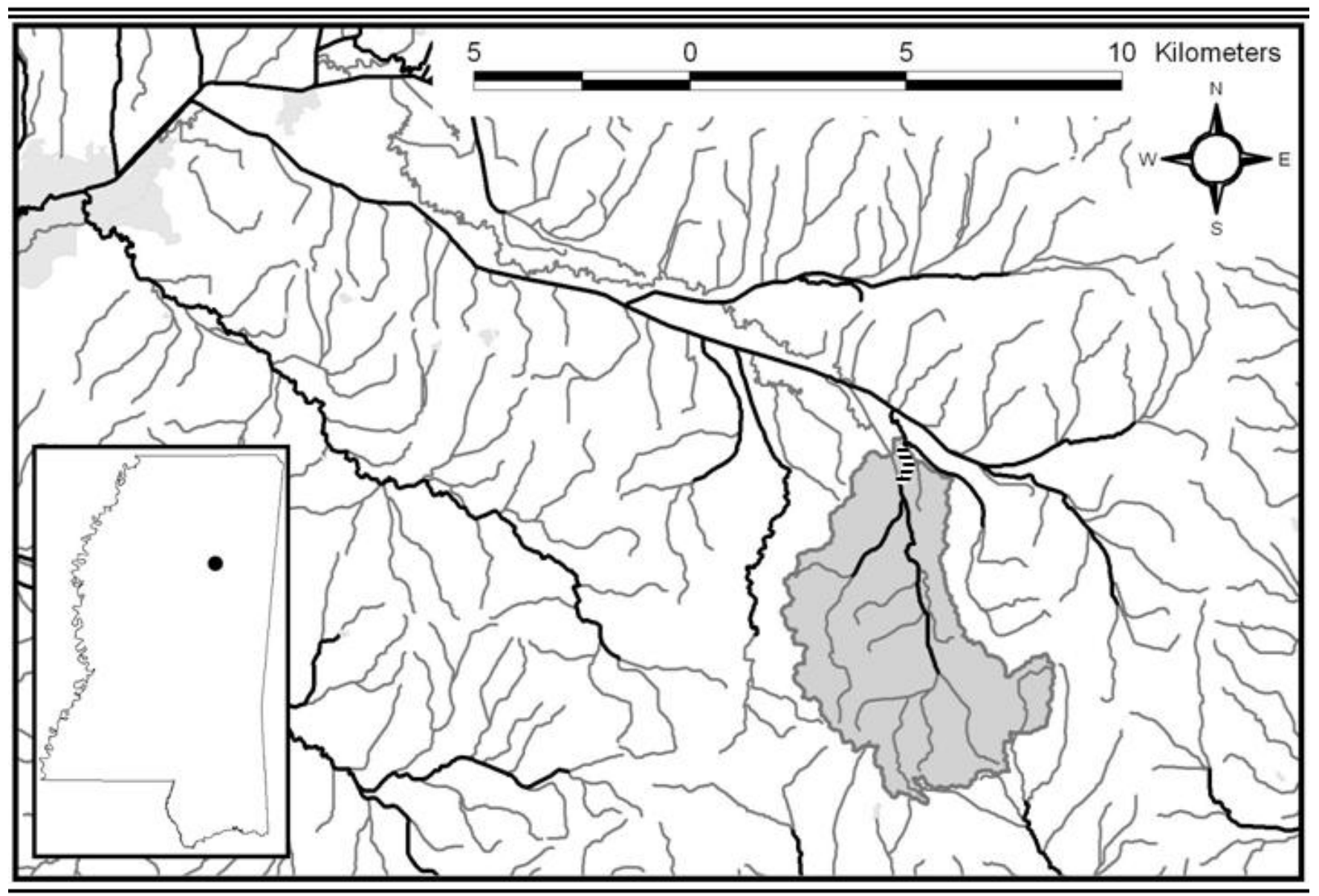

periods (Wilson et al. 2007). Cavities from past seepage events were common in steep banks. The significance of bank undercutting caused by seepage erosion has been indicated by recent laboratory investigations (Fox et al. 2006, 2007b, Wilson et al. 2007) and numerical analysis (ChuAgor et al. 2008).

Although headcut migration, width adjustment, and berm formation observed in the reach were characteristic of incised channel evolution (Simon 1989), fluvial behavior was perturbed by meandering and sediment production from upstream headcuts (Wallerstein 2000). Headcuts (knickpoints) were found downstream, within the study reach, and upstream. Approximately $60 \mathrm{~m}$ of headward migration of a $0.6 \mathrm{~m}$ high headcut and bank retreat as great as $7.6 \mathrm{~m}$ were observed during a single storm event in the study reach. At least two abandoned meanders in the study reach suggested recent natural neck cutoffs. Concave banks on the outside of meander bends failed because of mass wasting, and sand accreted on large point bars opposite failing banks. Interestingly, several point bars were dissected during high flows, leaving large sand deposits along the toe of concave outer banks. 
Fig. 2. Daily precipitation and hourly stream stage and water table elevation for the study reach of Little Topashaw Creek, Mississippi. Source: Pezeshki et al. (2007).

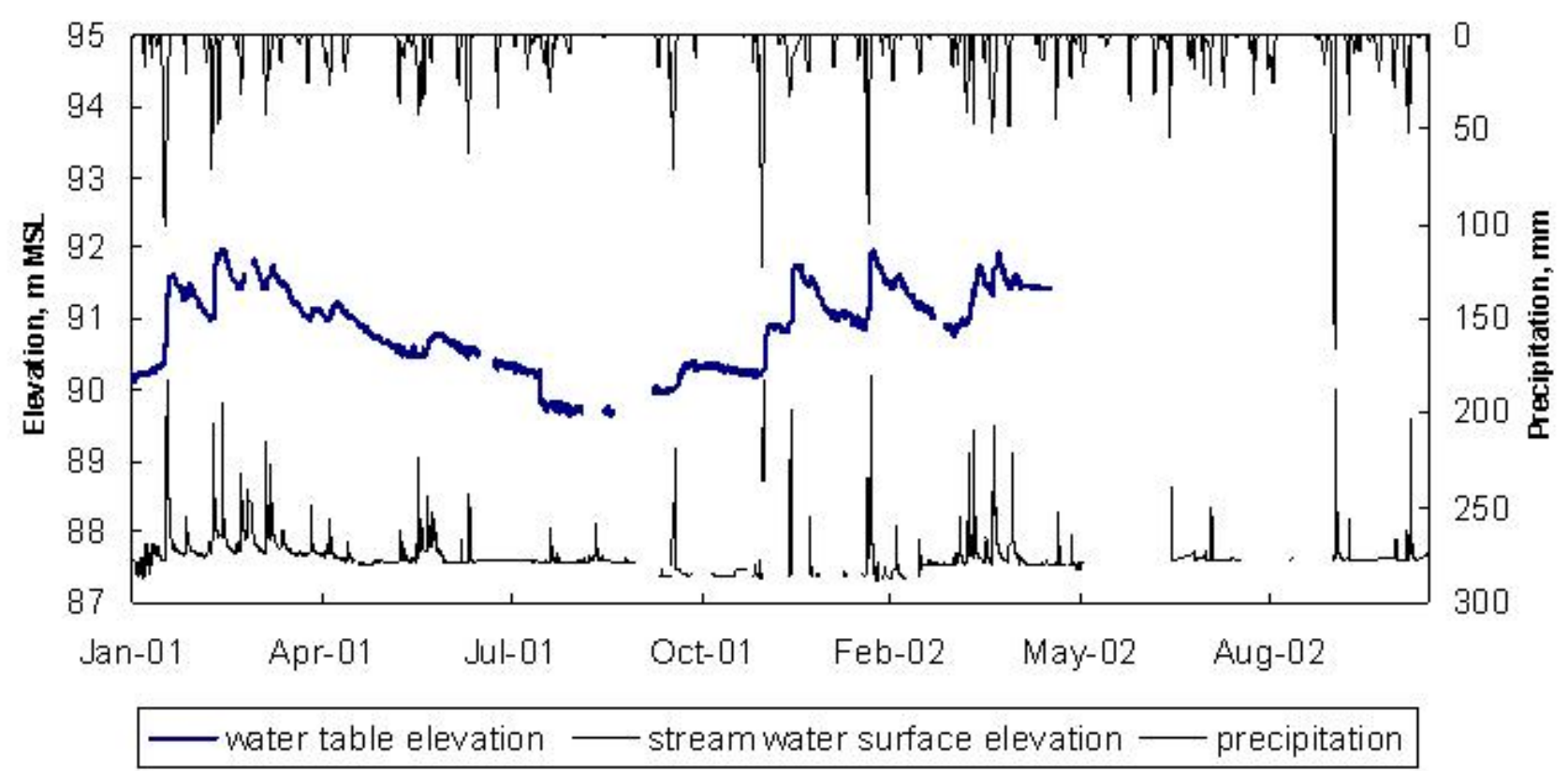

The channel therefore became straighter and possibly steeper during the process of degradation. This process occurred both before and after rehabilitation in treated and untreated reaches.

Bank failures contributed significant inputs of large wood to the study reach, but the channel was so wide that retention rates were low. Prior to rehabilitation, only $39 \%$ of $\operatorname{logs}$ located within the channel top banks remained in the same place $1 \mathrm{yr}$ later (Shields et al. 2004). Retention rates for smaller organic particles were also low. The total carbon (assumed to be equal to total organic carbon because of the
$\mathrm{pH}$ regime) of bed sediments averaged $0.13 \pm 0.08 \%$ prior to rehabilitation, which was comparable to means of $\sim 0.25 \%$ for relatively less disturbed streams in the same region (Stofleth et al. 2004).

Along the outside of bends, eroding banks frequently invaded adjacent cultivated fields, whereas inside bends and abandoned sloughs were vegetated with a diverse mixture of hardwood trees and associated species. Bar sedimentation rates appeared to be quite rapid because few young trees were evident on the point bars. A botanical survey revealed 18 vascular plant families and 51 species 
Fig. 3. Physical instability along Little Topashaw Creek prior to rehabilitation. (A) Bank erosion, (B) headcut advancement, $(\mathrm{C})$ riparian gully erosion.

(A)

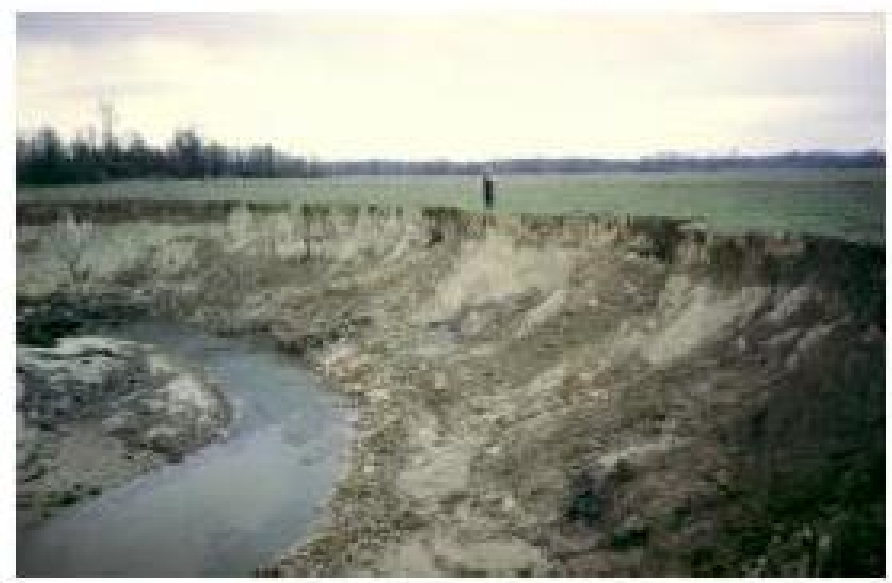

(B)

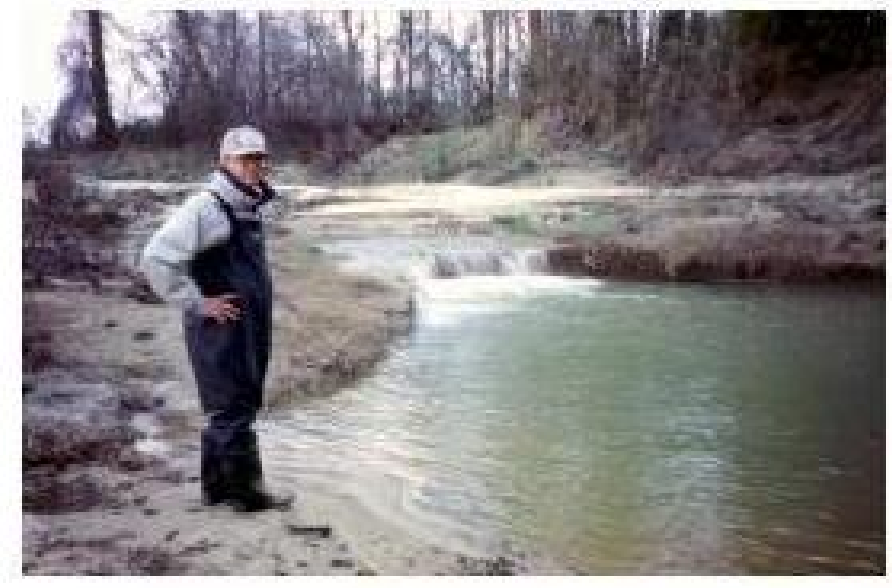

(C)

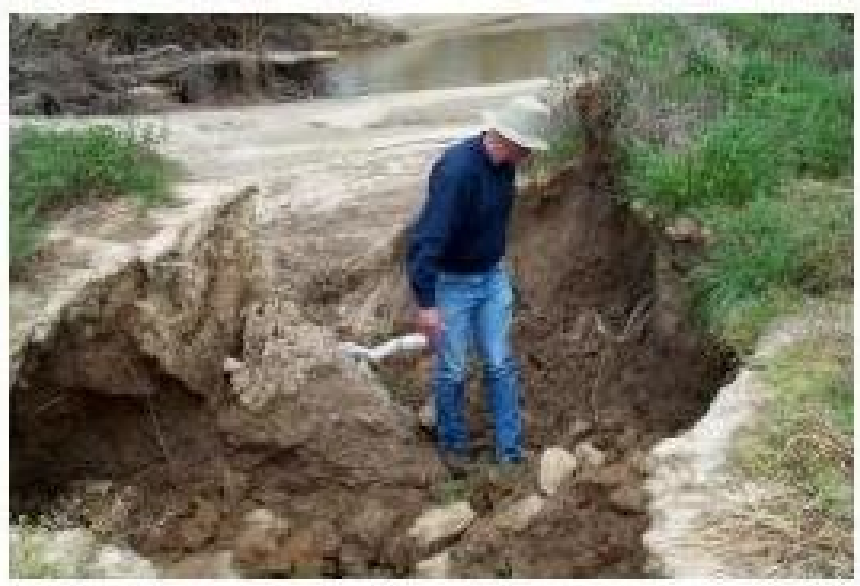


on streambanks and adjacent top banks within the study reach (Davis 1999). Within the channel proper, the abundance of plants was low and consisted mostly of tolerant herbaceous species. The abundance of plants increased with increasing distance from the base flow channel, and the species composition became similar to that of the plants that were found immediately adjacent to the agricultural fields. The exotic vine kudzu (Pueraria lobata) covered much of the streambanks in the downstream reaches and often entirely covered trees and shrubs.

\section{REHABILITATION PROJECT}

A channel stabilization and habitat rehabilitation project was planned and designed for a $2 \mathrm{~km}$ long reach of Little Topashaw Creek to develop low-cost, low-maintenance practices feasible for implementation by landowners. Habitat rehabilitation was intended to return partially the stream corridor ecosystem to its historic (pre-degradation) trajectory (Society for Ecological Restoration International Science and Policy Working Group 2004), with the characteristics of the target trajectory inferred from characteristics of a lightly degraded stream in the same region (Shields et al. 1994, 1998, 2006). We selected restoration practices for testing that would be applicable at the landscape scale. Further, we selected practices that could provide acceptable levels of stability and conveyance by working with geomorphic processes to produce natural forms and functions. This final criterion was critical because three of the four selected practices featured almost exclusive use of plant materials. The practices tested included large wood stabilization and habitat structures; the planting of willow cuttings on sediment bars and eroding banks; the planting of switchgrass hedges in riparian gullies; and the stabilization of steep, eroding banks by dewatering using passive drains and solar-powered wells. Willows were planted for US\$7.50 per cutting, and large wood (LW) structures cost US $\$ 80$ per meter of treated bankline. The $2-\mathrm{km}$ reach was treated with LW structures and willow plantings for a total of US\$176,000, exclusive of costs for planning, design, contract administration, and monitoring. Construction costs were 20 to $50 \%$ of the cost for the contemporary construction of traditional stone stabilization (Martin et al. 2005, Pezeshki et al. 2007).

\section{Large wood}

A total of 72 wedge-shaped LW structures were constructed on concave, eroding banks by stacking either woody debris $(\sim 10 \%)$ or living trees $(\sim 90 \%)$ in a criss-cross arrangement (Fig. 4; USDA 2006a). LW structure dimensions averaged $13.9 \pm 3.9 \mathrm{~m}$ in the streamwise direction and $5.3 \pm 1.0 \mathrm{~m}$ in the transverse direction and were $2.1 \pm 0.5 \mathrm{~m}$ high. Fifty-eight of the structures were secured to the bed by four or more earth anchors secured to the streambed. To build the structures, 1168 trees were obtained by clearing 3.4 ha of fencerows and ditchlines $>10 \mathrm{~m}$ from the top bank of the channel. Most trees were harvested $>200 \mathrm{~m}$ from the channel, and no impacts of tree harvest on channel morphology or habitat were observed. Most trees were oak (Quercus sp.), but ash (Fraxinus sp.), cherry (Prunus sp.), hickory (Carya sp.), elm (Ulmus sp.), sweetgum (Liquidambar styraciflua), and sycamore (Platanus occidentalis) were also used (Shields et al. 2004).

\section{Willows}

Approximately 4000 willow (Salix nigra) cuttings were planted on point bars and in sediment deposits adjacent to selected LW structures using a waterjetting technique (Drake and Langel 1998; Fig. 5). Willow cuttings were soaked for 2-3 weeks prior to planting to improve transplant success (Schaff et al. 2002, Martin et al. 2004). A subset of the willows was planted in square plots selected to represent a range of soil textures and vertical distances from the base flow channel to relate willow growth and survival to environmental conditions. Half of the cuttings planted in the plots were soaked for 10-12 days prior to planting, and half were planted immediately after they were harvested locally.

\section{Gully treatments}

Fourteen edge-of-field gullies (side inlets) were identified and surveyed along both banks of the study reach. Six of these were designated for treatment with switchgrass hedges, leaving eight as untreated controls. Three of the treated gullies were shaped to smooth contours (slopes $\leq 1: 2.5$ vertical: horizontal) using a track hoe prior to planting, and three were planted using only hand labor. Hedges 
Fig. 4. A large wood (LW) structure deployed at Little Topashaw Creek. (A) Design plan and profile. (B) LW structure 5 months after construction; note sediment deposits within the structure. (C) The same structure in (B) 9 months after construction. (D) The same structure in (B) completely disappeared $3 \mathrm{yr}$ after construction.

(A)
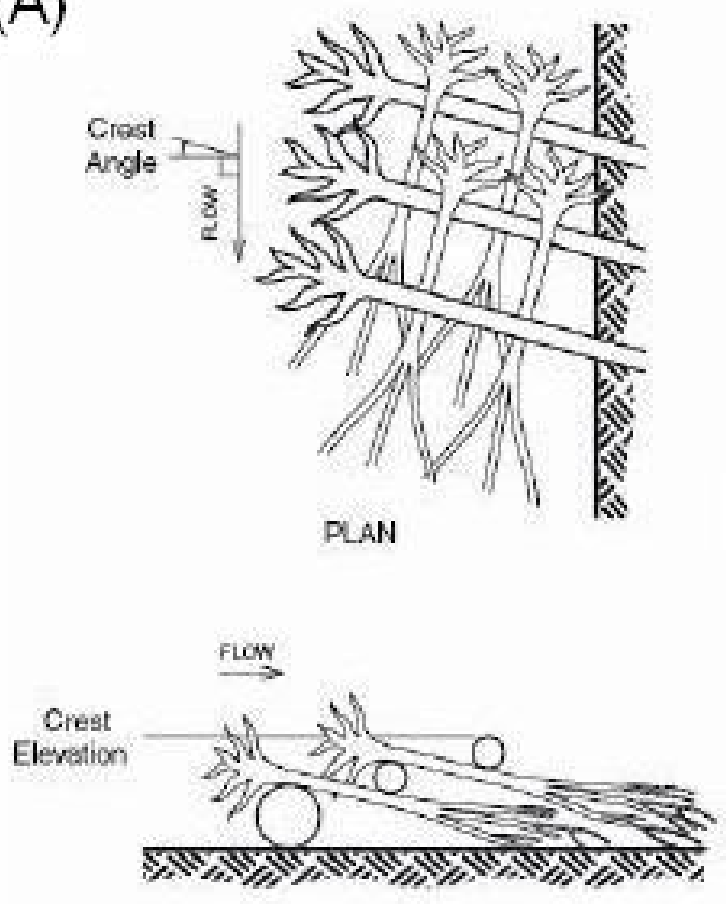

ELEVATION
(B)

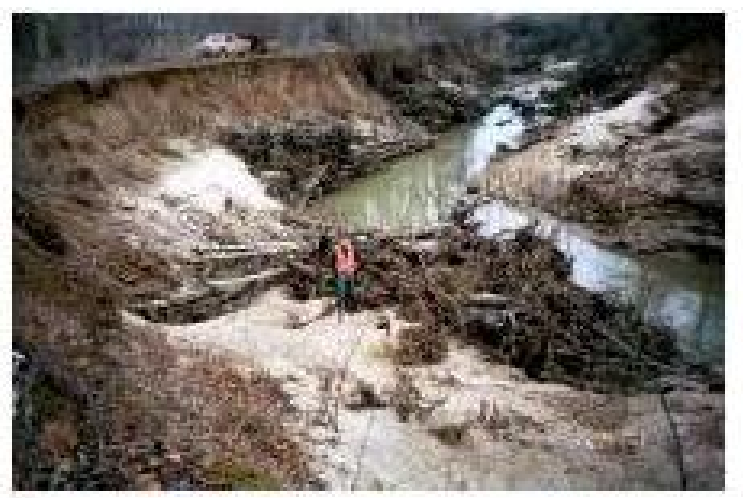

(C)

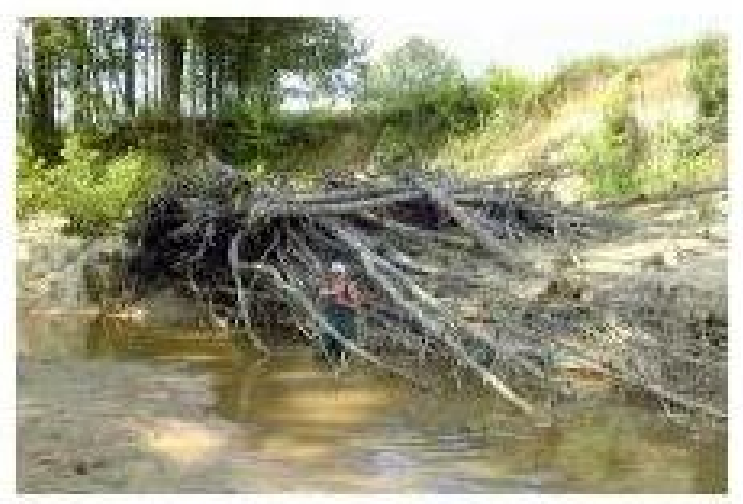

(D)

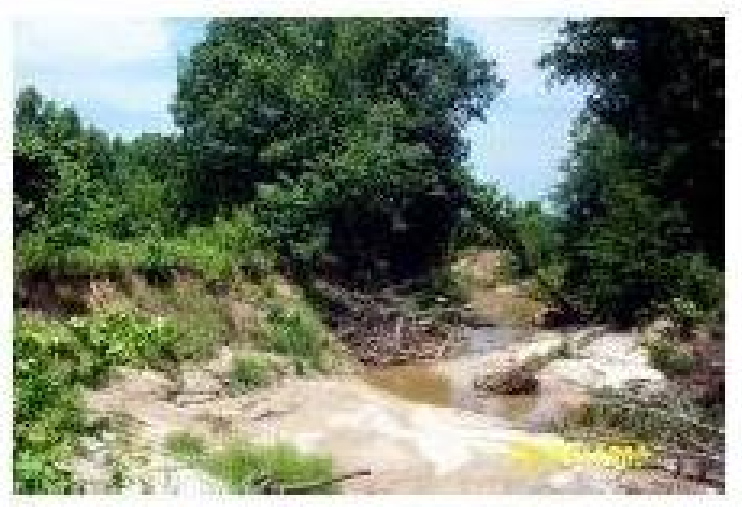


Fig. 5. Willow cuttings planted at Little Topashaw Creek. (A) Willows being planted using water jetting. (B) Initial willow stand 4 months after planting, showing effects of herbivory. (C) The same location in (B) 3 yr later, showing no survivors.

\section{(A)}

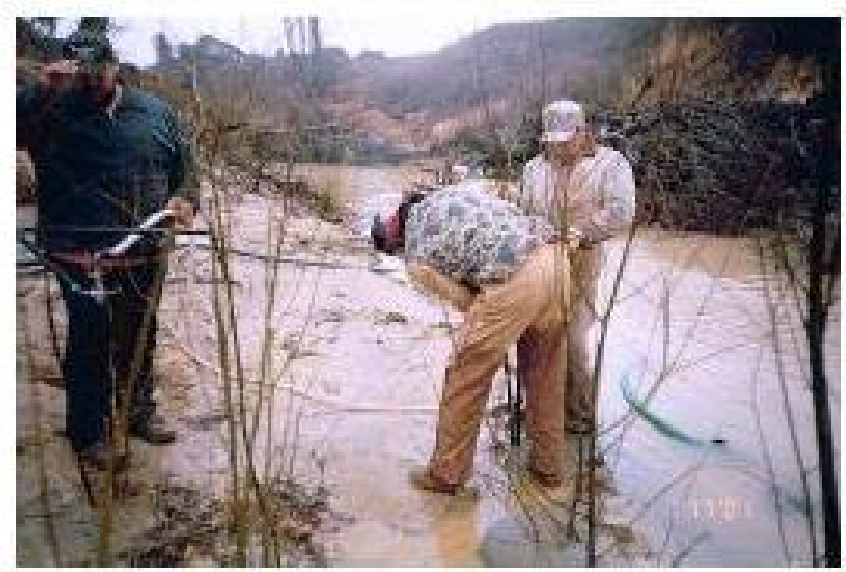

(B)

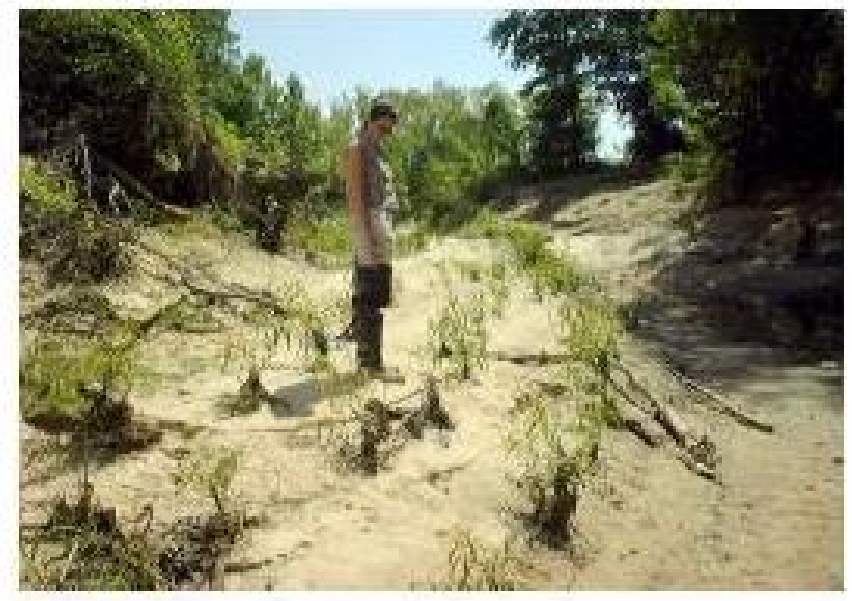

(C)

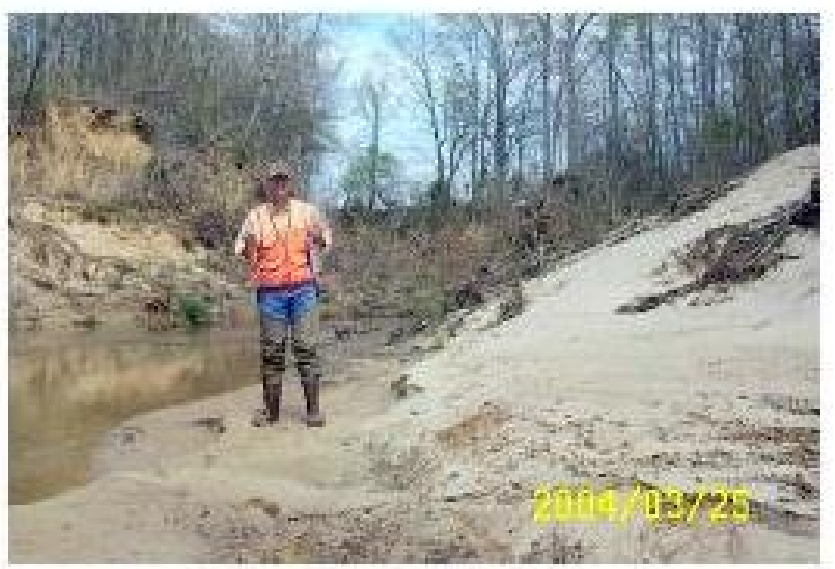


were initially planted in June 2000 using transplanted strips of locally grown native switchgrass (Panicum virgatum L.) sod (Fig. 6). Hedges were placed perpendicular to the longitudinal axes of the gullies at $0.5-\mathrm{m}$ vertical intervals. One of the shaped gullies was subjected to a series of simulated flow events by pumping water from the creek into the gully in February 2002 when the hedges were well established (Dabney et al. 2004). Intensive maintenance, i.e., replanting, diverting flow during grass establishment, and using matting and temporary check dams, was employed as described by Shields et al. (2005).

\section{Bank dewatering}

Streambank instability as a result increasing soilwater pressure (Simon and Curini 1998, Casagli et al. 1999, Simon et al. 2000, Rinaldi et al. 2004) and seepage erosion (Fox et al. 2007a, Chu-Agor et al. 2008) were addressed by dewatering the soil profile that composed parts of a $6 \mathrm{~m}$ high eroding bank (Shields et al. unpublished manuscript; Figs. 3A and 7A). The outside bank of a bend was divided into three study plots separated from each other by approximately $25 \mathrm{~m}$. At the first plot, two pairs of $5 \mathrm{~cm}$ diameter boreholes were installed $15 \mathrm{~m}$ apart to depths of 2 and $4 \mathrm{~m}$ (Fig. 7B), and a solar-powered peristaltic pump was installed in each borehole. Pumps discharged into the creek. The pumps were activated by float switches controlled by tensiometers. The second plot was an untreated control equipped with a nest of tensiometers to monitor the soil-water pressure profile. The third plot was treated by installing two $10 \mathrm{~cm}$ diameter perforated plastic drain tile lines $\sim 1.5 \mathrm{~m}$ deep perpendicular to the bank and extending $\sim 10 \mathrm{~m}$ into the field. The drain lines were placed approximately $20 \mathrm{~m}$ apart. One of the lines had an additional $10 \mathrm{~m}$ of tile that turned 90 degrees and ran an additional $10 \mathrm{~m}$ parallel to the top bank (Fig. 7A).

\section{Monitoring}

Monitoring was a major component of the project (Table 1; USDA 2008). Data acquisition focused on system inputs, boundary conditions, and environmental responses. Measurements of environmental responses included data collected before and after rehabilitation and up- and downstream of the treated reach. The performance of the rehabilitation practices was monitored by frequent visual inspections; topographic surveys of large wood, bank dewatering, and gully treatment; and measurements pertaining to the growth and physiology of the willow cuttings. In most cases, the resultant data are available from F. D. Shields upon request.

\section{RESULTS}

Fourteen discharge events $>20 \mathrm{~m}^{3} / \mathrm{s}$ occurred during the study: three in the first few months after construction, and the remainder during the following three years. High flows lasted only a few hours, with brief rise times and sharp peaks. The Richards-Baker flashiness index for mean daily discharge during four complete years of the study ranged from 0.87 to 1.35 , which is comparable to a range of 0.05 to 1.05 for $27-y r$ average values computed for streams with watersheds of this size in the U.S. Midwest (Baker et al. 2004). Flashiness was further highlighted by computing indices of hydrologic alteration (Richter et al. 1998) using mean daily stages for the study reach and for a nonincised stream with the same size of watershed (i.e., Toby Tubby Creek; Shields et al. 1994, 1998). The median rise and fall rates for the incised study reach were 6.4 and 1.6 times greater than for the nonincised stream.

\section{Short-term successes}

Initially, the large wood (LW) structures were quite effective at modifying flow fields, trapping sediments, and stabilizing steep banks (Shields et al. 2004, 2006). During the high flow season prior to construction, measured top bank retreat rates were $1.1 \pm 1.7 \mathrm{~m}$, but these declined to $0.44 \pm 0.66$ $\mathrm{m}$ during the first year following construction. Sixty-eight of the 72 structures survived the first high flow season, and almost all accreted significant volumes of sediment (Fig. 4B). Local scour adjacent to structures and backwater from small beaver dams resulted in greater base flow water depths and greater levels of habitat heterogeneity following LW placement. The mean measured water depth increased from $\sim 6 \mathrm{~cm}$ before construction to $\sim 11$ $\mathrm{cm}$ afterward, and the standard deviation of depth increased by $70 \%$. Large wood density (the area of LW in the plane of the water surface and channel 
Fig. 6. Riparian gully stabilization using switchgrass hedges at Little Topashaw Creek. (A) Gully immediately after shaping and planting, showing silt fences placed just below each grass hedge. (B), (C) Development of grass during the first growing season. (D) View from the stream channel 3 yr after planting.

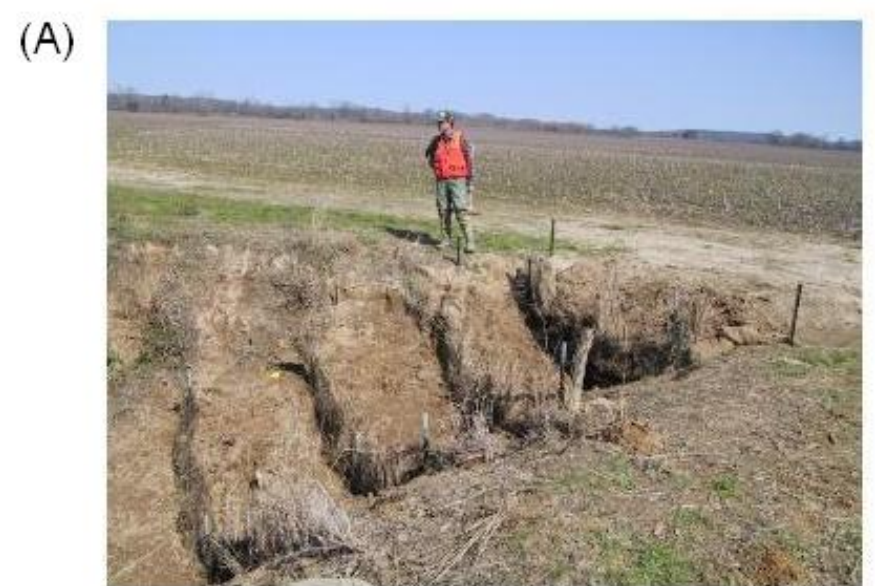

(B)

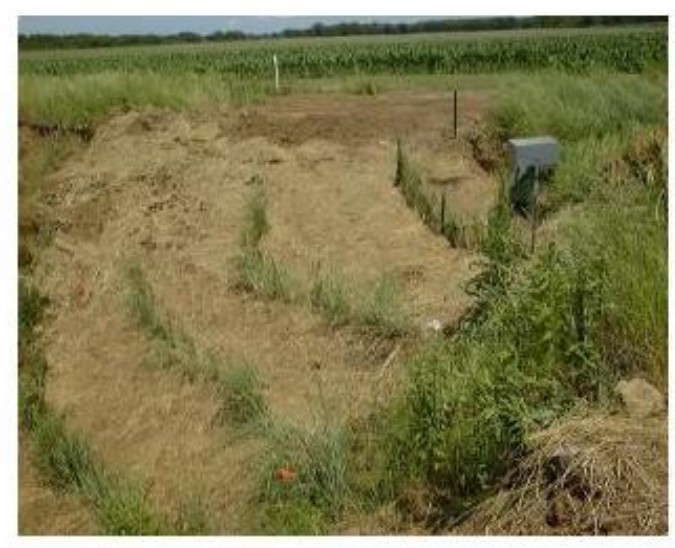

(C)

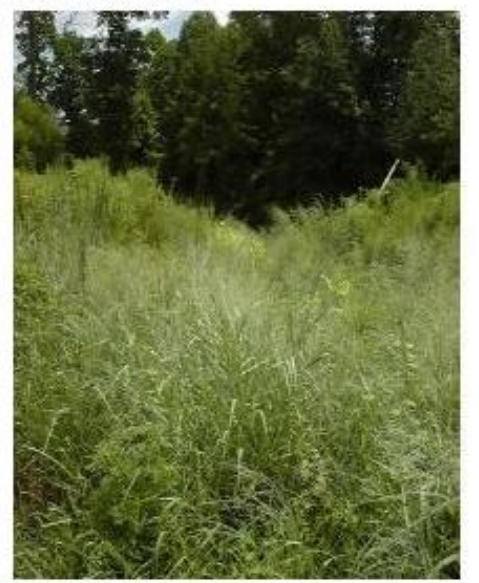

(D)

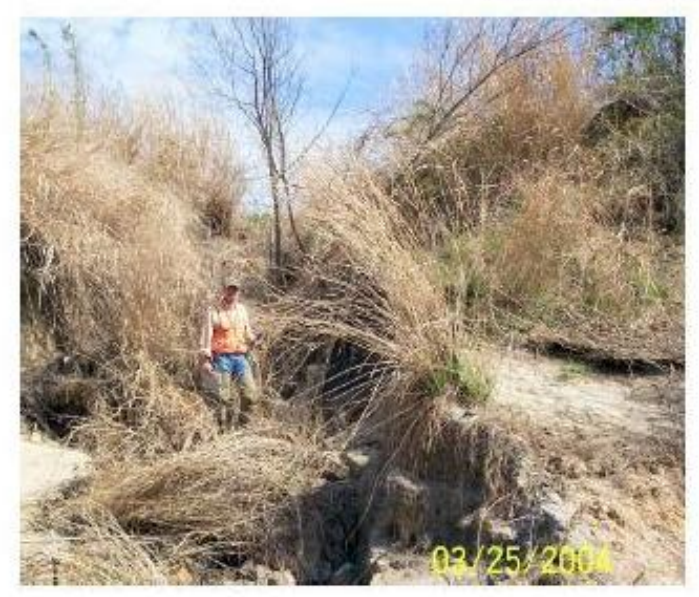


Fig. 7. Bank dewatering using pumps and drains. (A) Plan of the dewatering plots. (B) Schematic profile of the pumped plot.

(A)
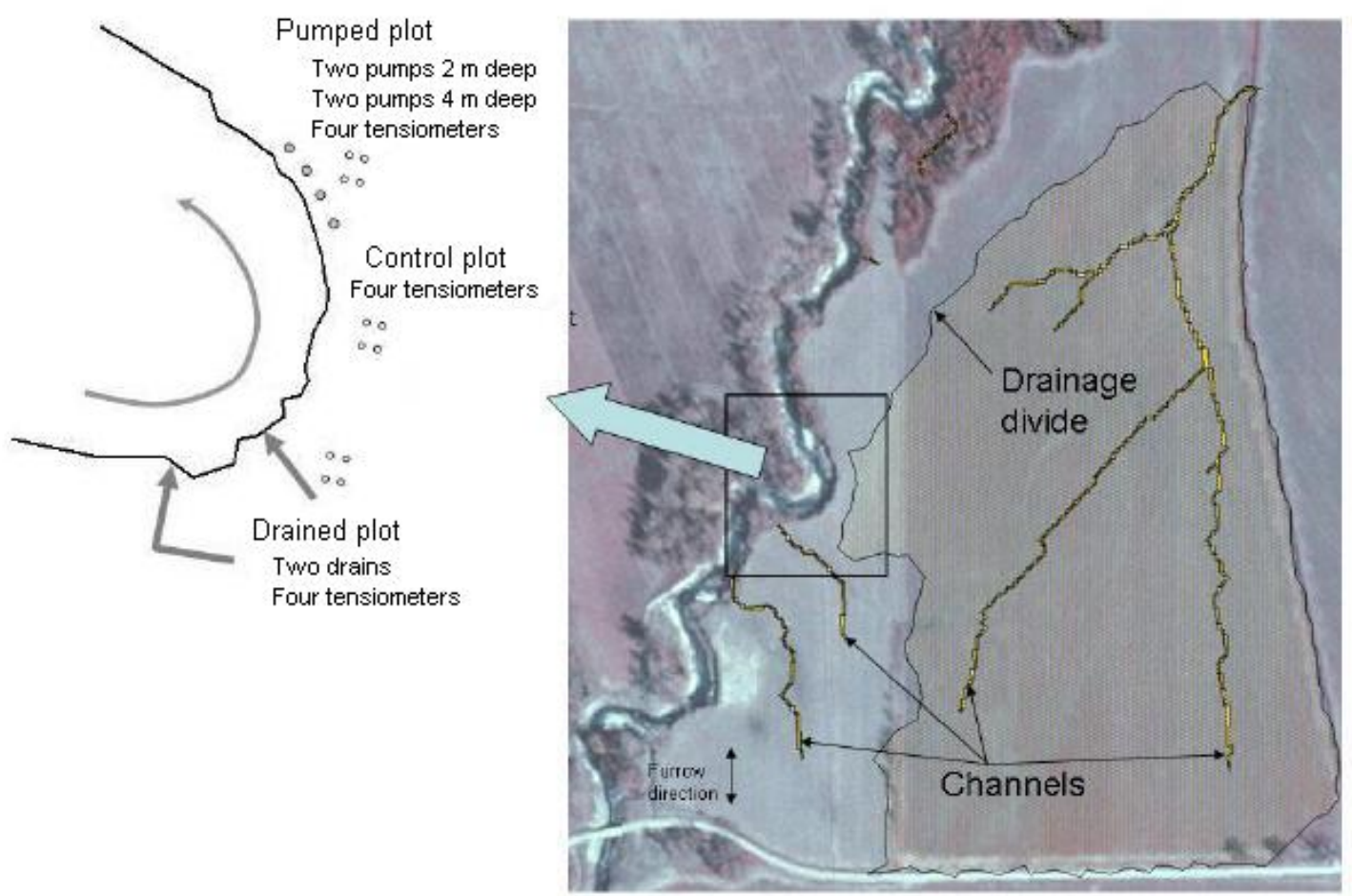

(B)

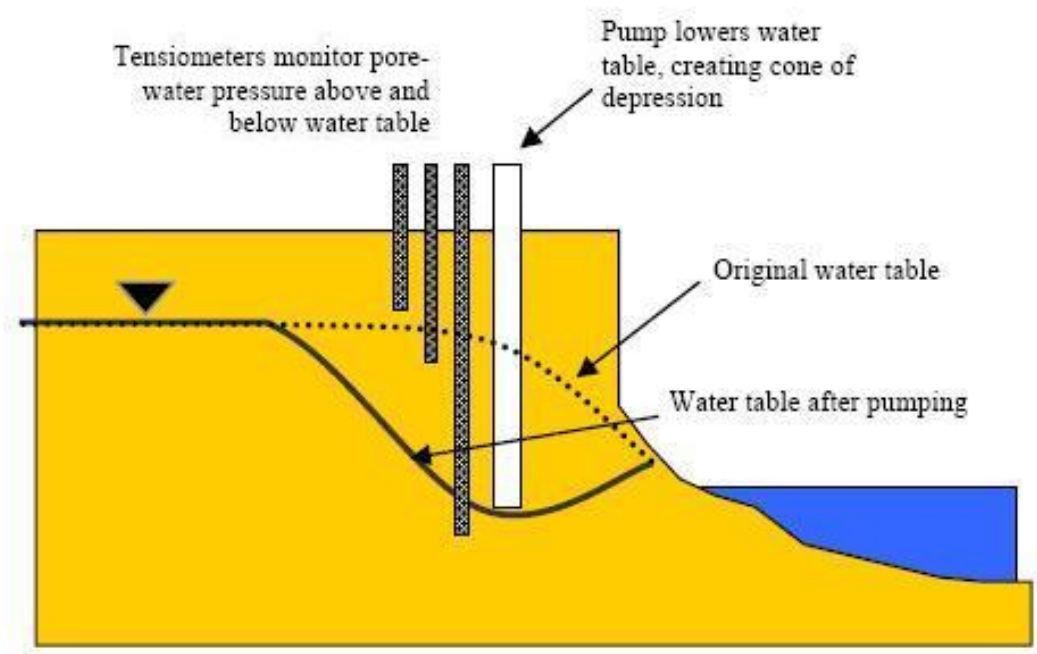


Table 1. Monitoring activities that were performed during the Little Topashaw Creek Stream Corridor Rehabilitation Project.

\begin{tabular}{llll}
\hline \hline Project component $\quad$ Pre construction only & $\begin{array}{l}\text { Pre and post } \\
\text { construction }\end{array}$ & Post construction only Reference
\end{tabular}

General

(1)

Large wood structures

Willow plantings

Soil texture of study plots

Geomorphic assessment

Stratigraphy

Terrestrial macrophytes

Resistance of cohesive bed material to erosion

Precipitation; stage streamflow

Water quality

Hyporheic and total transient storage

Channel cross sections thalweg profile; bed material size

Instream physical aquatic habitat

Macroinvertebrates

Fish

Bed carbon content

Depth to shallow groundwater; soil redox potential

Gully plantings

Gully numbers, locations, and contributing drainage areas

Dewatering pumps and Soil characteristics drains

Gully morphology

Site topography; bankline position
Wallerstein 2000

Adams 2000

Davis 1999

Hanson and Simon 2001

Pezeshki et al. 2007

Smith et al. 2006

Stofleth et al. 2008

Shields et al. 2004 structures

High flow depths and velocities inside and adjacent to structures

Shields et al. 2003, 2006

Testa and Cooper 2002, Cooper et al. 2004

Shields et al. 2006

Stofleth et al. 2004, Shields et al. 2008

Survival and growth; Martin et al. 2005, plant gas exchange; leaf chlorophyll content

Soil characteristics; hedge and stem sizes; flow hydraulics and soil water potential during simulated events

Pezeshki et al. 2007

Dabney et al. 2002, 2004, Shields et al. 2005
Shields et al. unpublished data
Soil water potential; pump and drain discharge 
bed area) tripled after treatment. Effects on stream base flow velocities were quantified using sluginjection tracer dye studies in the rehabilitated reach and in an untreated reach immediately downstream that had similar hydraulic roughness and channel geometry. The mean velocity in the treated reach was $0.17 \mathrm{~m} / \mathrm{s}$, but was $0.29 \mathrm{~m} / \mathrm{s}$ in the untreated reach (Shields et al. 2003, 2006). These findings were further confirmed by measurements of total transient storage in a segment of the rehabilitated reach before and after the addition of a large cylinder that was designed to mimic an underflow debris jam (Stofleth et al. 2008). The addition of the underflow jam increased the fraction of median travel time due to storage by a factor of two.

LW also exerted an important influence on habitats during high flow events (Shields et al. 2003, 2006). Acoustic Doppler loggers were used to record high flow current velocity magnitudes at the bank toe and at the channel centerline adjacent to the structures in a tight bend. Prior to the placement of LW structures, the highest velocities within bends occurred at the bank toe, but an LW structure placed at the bank toe created a velocity shelter. Velocities within the LW structure were usually $<0.10 \mathrm{~m} / \mathrm{s}$, even during events that were large enough to produce flow depths $>3 \mathrm{~m}$. Such low velocities are well within the preferred ranges for centrarchid and ictalurid fishes (McMahon and Terrell 1982, Stuber et al. 1982). Velocities measured in the channel adjacent to the structure were approximately three times greater than those within the LW matrix. The measured velocities were used to calibrate a twodimensional model of flow and sediment transport for the entire meander bend. The model incorporated the effects of the LW structures and secondary currents typical of bends (Fig. 8; Wu et al. 2005). The model output showed significant regions of velocity shelter and sediment deposition associated with LW structures (Fig. 8C).

Deep channel incision and the attendant flashy hydrology produced drier conditions in upper banks, particularly in banks with sandy soils, which were common even in steep banks. After two growing seasons, the mean willow survival was only $\sim 50 \%$ in study plots that were $>0.5 \mathrm{~m}$ above the stream at base flow, whereas survival in lower plots averaged $86 \%$ (Pezeshki et al. 2007). The soaking of cuttings before planting was beneficial, resulting in $17 \%$ higher mean survival and $6 \%$ greater leaf chlorophyll content. The effects of soaking were most pronounced for cuttings that were subjected to harsh conditions, i.e., drier locations or grazing by beaver (Martin et al. 2005). The soil sand content was also a key factor in willow survival. At the end of the second growing season, survival in plots that had a mean sand content of $\sim 65 \%$ was approximately $65 \%$, whereas survival in plots that had a mean sand content of $87 \%$ was only $36 \%$.

Pumped flow tests indicated that grass hedges could provide short-term erosion control for flows up to $0.15 \mathrm{~m}^{3} / \mathrm{s}$ if the gully steepness was $<0.3 \mathrm{~m} / \mathrm{m}$ and hedges were established with a vertical interval $\leq$ $0.5 \mathrm{~m}$. Root reinforcement rendered this height stable against block failure (Dabney et al. 2004).

High, sandy banks were harsh habitat for planted or natural vegetation during dry periods, but elevated soil moisture and the attendant loss of matric suction (negative pore-water pressure) contributed to mass failures during wet periods. The solar-powered pumps and passive drains reduced soil moisture and provided improved stability relative to the adjacent untreated control (Shields et al. unpublished data). Over the course of two wet seasons, the average bank retreat for the control, pumped, and drained plots was $0.43,0.21$, and $0.23 \mathrm{~m}$, respectively. At the pumped site, the matric suction was $3-4 \mathrm{kPa}$ higher than that at the control site during the most critical periods. Accordingly, computed factors of safety were above the failure threshold at the pumped site, but fell below unity (i.e., became unstable) at the control site on 11 occasions over the period of observation. Similarly, the drained site generally displayed higher matric suction and higher factors of safety than did the control site, except during two events when the drains were evidently overwhelmed by the volume of local surface and subsurface flows.

Macroinvertebrate community indices (i.e., Simpson index, Shannon index, and evenness) showed positive responses to LW during the first two years after construction (Cooper et al. 2004). Overall, the numbers of individuals were very similar before and after rehabilitation efforts, whereas the number of taxa increased by approximately $30 \%$ following rehabilitation. Only $40 \%$ of the observed taxa were found both before and after rehabilitation. Accordingly, incidencebased similarity measures indicated a major shift in assemblage composition following rehabilitation. The Shannon index and Fisher's log series alpha index indicated low overall diversity before treatment and much greater diversity after structure 
Fig. 8. Numerical simulation of the effects of large wood (LW) structures on a meander bend on Little Topashaw Creek. (A) Topography and LW locations. (B) Simulated flow field at a discharge of $43 \mathrm{~m}^{3} / \mathrm{s}$. (C) Simulated bed change after 1 yr due to erosion and deposition.

(A)
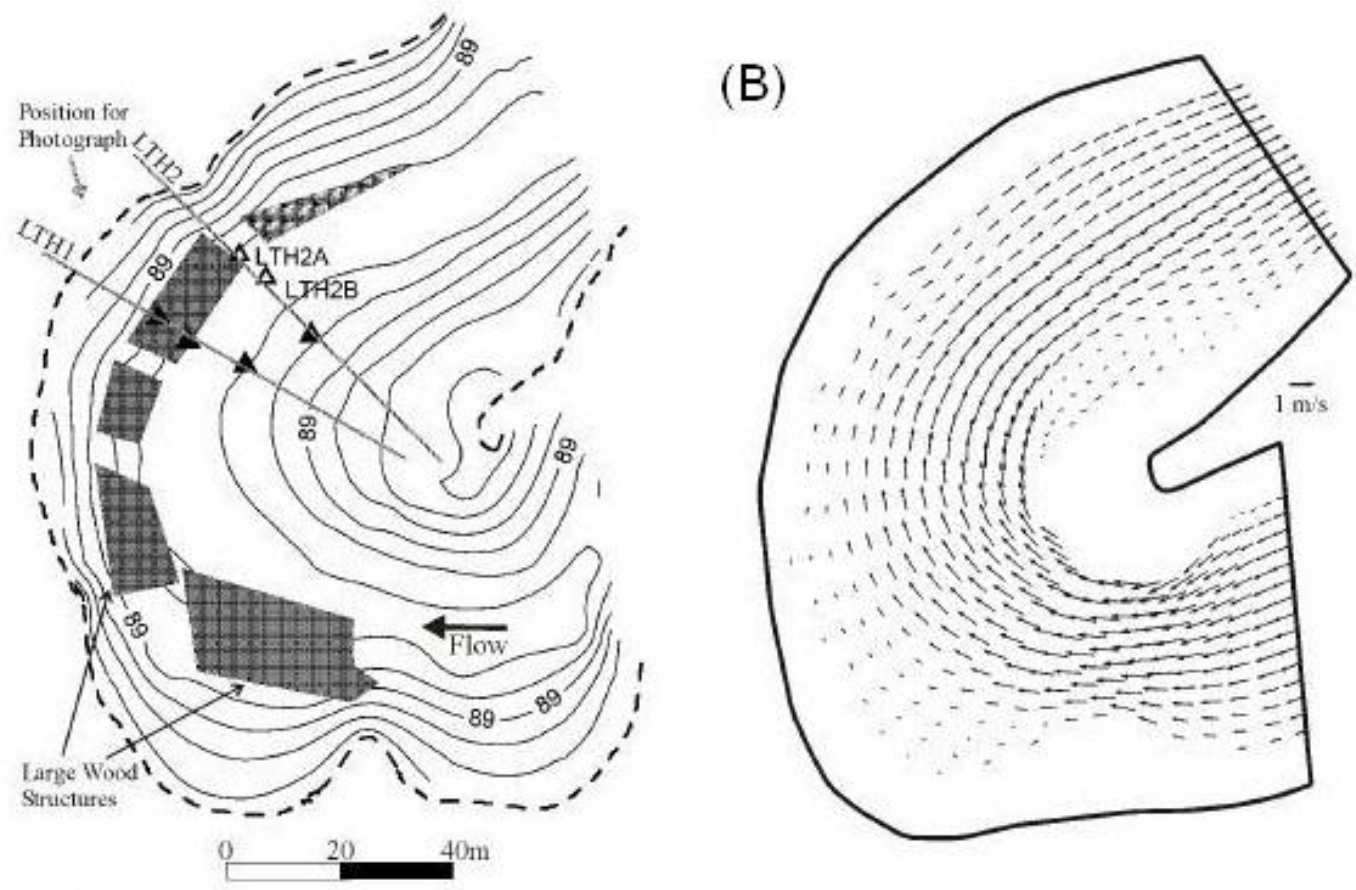

(C)

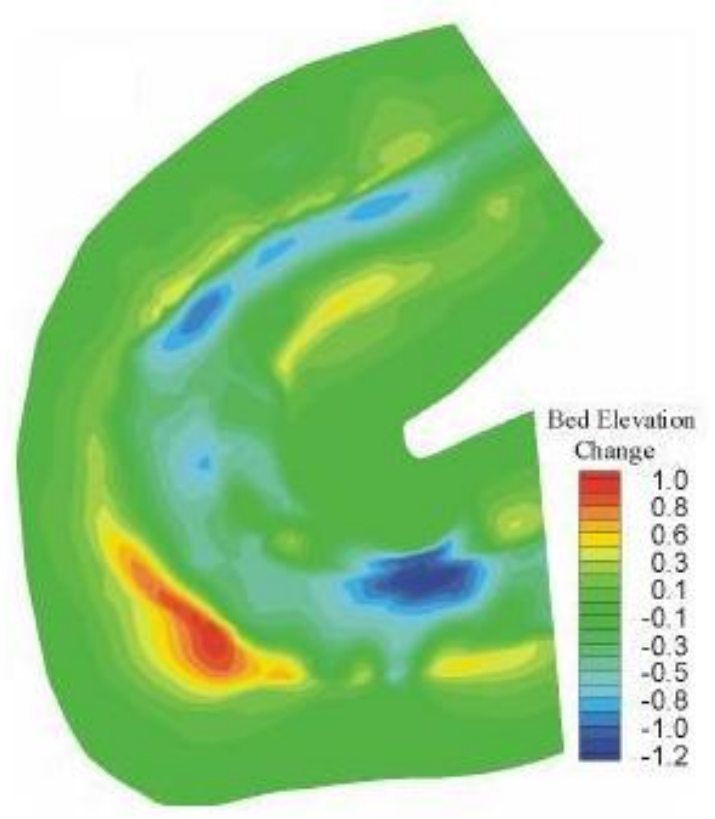


placement, but this greater diversity was still lower than expected for healthy streams in the region.

Prior to restoration, the study reach supported a colonizing fish assemblage (sensu Schlosser 1987) dominated by small-bodied opportunists such as juvenile cyprinids typical of incised streams in the region (Shields et al. 1998, Adams et al. 2004). Schlosser (1987) suggested that colonizing assemblages occur in systems with flashy hydrology, severe droughts, and a scarcity of pool habitats for cover and refugia. The average fish species richness increased in the post-construction period for both treated and untreated reaches. However, the increases were slightly greater in the modified and downstream reaches. All collections were numerically dominated by cyprinids and centrarchids, but the relative dominance of cyprinids was inversely related to the mean water depth. Because the base-flow water depth increased following the installation of LW structures, there was a pronounced shift from small, opportunistic cyprinids to larger centrarchids, with the appearance of a few large predators. Similar shifts in other restoration projects within the region have signaled the recovery of community structures typical of less degraded streams. The appearance of larger individuals following the placement of $\mathrm{LW}$ structures is particularly significant. Fish age and size structure are diagnostic of conditions in less degraded streams where high habitat heterogeneity and deep, temporally stable pools allow fishes to withstand hydrological extremes and elude predators during the vulnerable juvenile phase (Webb and de Buffrénil 1990); fish food webs grow longer and more complex, leading to a decline in the dominance of generalists and the appearance of predators.

\section{Longer-term failures}

The physical instability of the study reach was only slightly ameliorated by rehabilitation, and flashy stream hydrology was not addressed by the reachscale measures. Thus, geomorphic processes overruled careful planning and design and dictated the outcome of the rehabilitation project. Although the large-scale measures of LW structures and willow planting were initially successful, at the end of the second year, $31 \%$ of the LW structures had been destroyed and $22 \%$ were damaged, and annual bank retreat rates had increased from to $0.44 \pm 0.66$ $\mathrm{m}$ to $1.6 \pm 4.9 \mathrm{~m}$. After $3 \mathrm{yr}, 36 \%$ of the $\mathrm{LW}$ structures were destroyed and 35\% were heavily damaged. Factors involved in failure included the simplification of LW matrices because of breakage and decay, scour of sediments deposited within the structures (Fig. 4B and C), and the failure of earth anchors (USDA 2006b). Structures that were located in sharp bends were most prone to fail. The damage rates were slightly higher for anchored LW structures (20 of 58 damaged) than for those without earth anchors (4 of 14 damaged). Of all anchors, $47 \%$ were located upon inspection $2 \mathrm{yr}$ after construction, and $61 \%$ of these were not functional. Evidently, the anchors, which were load tested to $4.5 \mathrm{kN}$ when installed, were undersized. The anchor sizing was based on LW structure design dimensions and the assumption that critical conditions would occur shortly after construction. Accordingly, a relatively high wood density of 750 $\mathrm{kg} / \mathrm{m}^{3}$ ) was used to compute net buoyant forces. Retrospective computations using as-built dimensions and a wood density of $450 \mathrm{~kg} / \mathrm{m}^{3}$ produced factors of safety well below unity.

For LW structure design, it was assumed that sediments deposited within the LW structure would add ballast to counteract the increased buoyant force associated with the drying of wood as the structure aged. A geomorphic assessment of the rehabilitation reach indicated that the period of channel deepening typical of incised channel evolution was ending; the natural tendency of the system favored the deposition of large sand berms within the enlarged, eroded channel. Initially, substantial volumes of sediment were captured by the LW structures (Fig. 4B). However, in many cases, sediments deposited during the first high flow season were scoured during the second, and approximately $0.3 \mathrm{~m}$ of thalweg degradation occurred throughout the reach.

Typical failure processes are illustrated by detailed data from one LW structure. Acoustic Doppler velocity loggers recorded the depth and velocity within and adjacent to an LW structure located at the apex of a bend with a ratio of top width to bend radius of $\sim 1.0$. During the rising limb of a large flow event that occurred approximately 16 months after construction, part of the structure apparently shifted, allowing velocities within the structure to increase rapidly from 0.2 to $1.2 \mathrm{~m} / \mathrm{s}$, greatly exceeding the critical level for the sandy bed material and approaching the velocity recorded at the adjacent channel centerline (Fig. 9). The structure failed shortly thereafter. 
Fig. 9. Water depth measured at the channel centerline adjacent to a large wood (LW) structure during a storm event on Little Topashaw Creek and simultaneous measurements of water depth and velocity within the structure. The sudden drop in the curve representing water depth within the structure corresponds to dislodgement of the log to which the sensor was attached. Note the increase in current velocity just prior to the movement of the log.

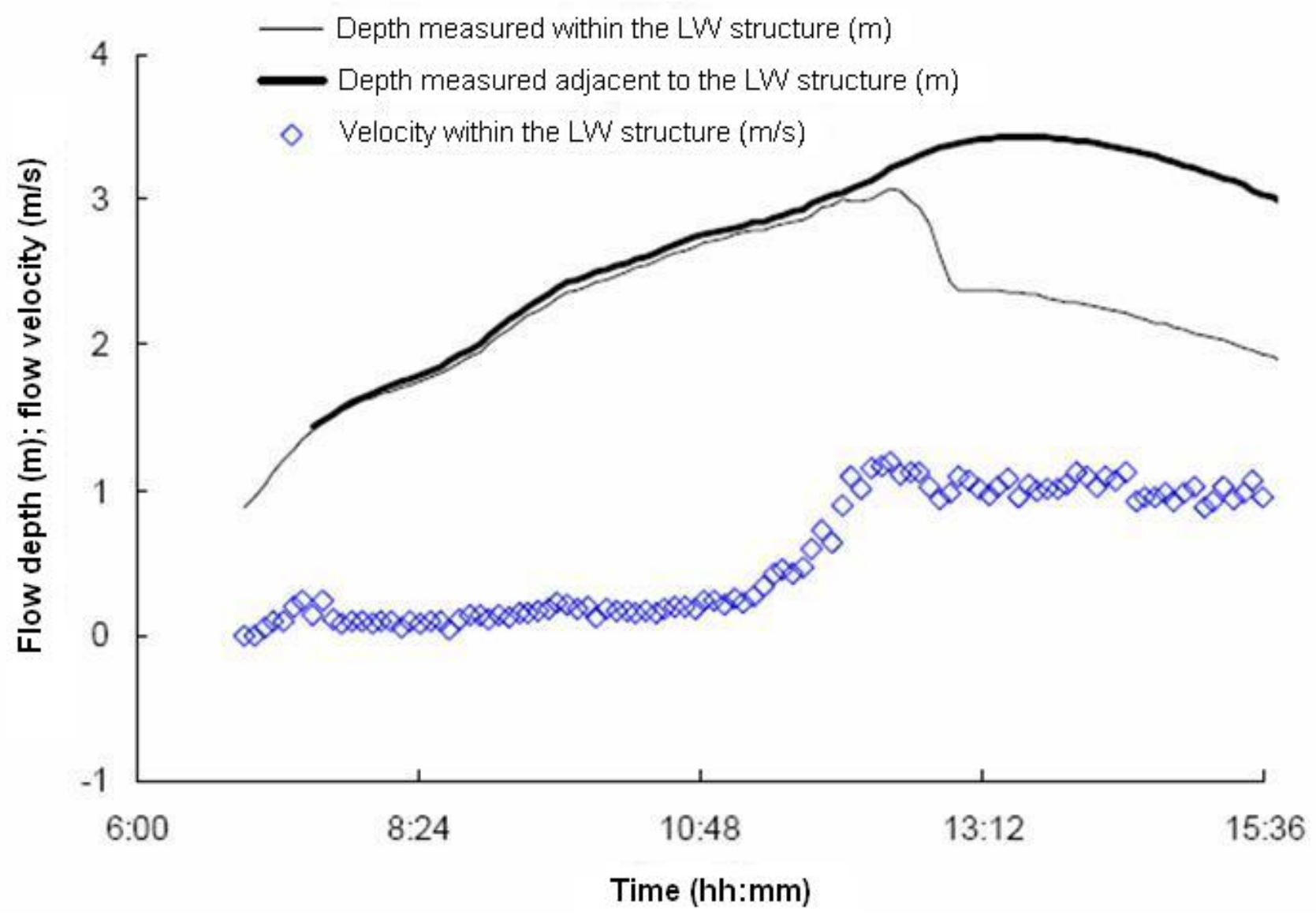

More than half of the monitored willows survived the first growing season and $>40 \%$ survived two seasons. However, a survey of all of the willow plantings at the beginning of the fourth growing season indicated that the survival rate was $<10 \%$ (Fig. 5B and C). Reasons for planting failure likely include erosion and sedimentation (channel stability), competition from exotics, and chronic herbivory by beaver (Pezeshki et al. 2007), although there were indications that limited, acute herbivory was not harmful (Li et al. 2005).
Although hedges were successfully established and effectively stabilized riparian gully side slopes (Fig. $6 \mathrm{~B}$ and $\mathrm{C}$ ), treated gullies were vulnerable to headcuts $>0.5 \mathrm{~m}$ high that advanced from the stream channel into the gully. Gully control with grass hedges failed in three modes (Dabney et al. 2004, Shields et al. 2005). The most immediate failure occurred at the gully toe, where sand bars up to $2 \mathrm{~m}$ deep either buried the hedges or did not provide a stable substrate for grass establishment. Large headcuts developed from the toe and progressed 
Fig. 10. Response of base-flow mean water depth and fish community composition (\% of catch biomass that was centrarchids) to the rehabilitation of Little Topashaw Creek. The vertical arrow indicates the date of rehabilitation.
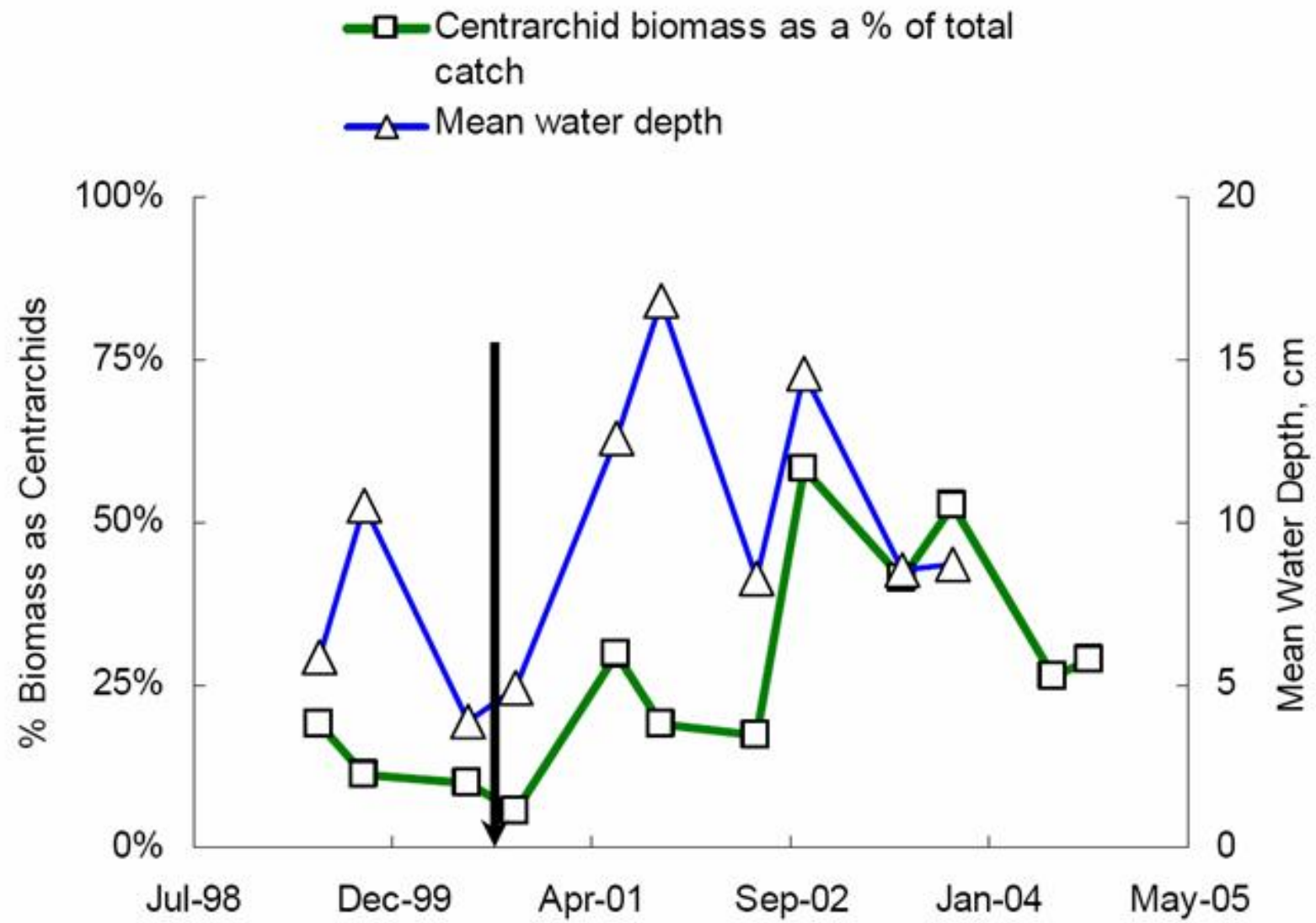

upslope. The second mode of failure occurred when the gully slope was too steep to allow the formation of plunge pools between hedges, leading to direct impingement of cascading flows onto exposed bare soil surfaces (Dabney et al. 2004). This mode of failure was most common on unshaped inlets. The third and most troublesome failure mode was the gradual grain-by-grain soil detachment that eventually washed the soil away from the grass roots, leading to deep incision through the grass hedges. Visual inspection of all of the treated gullies during the sixth year after treatment showed that all supported dense stands of switchgrass, but all were being dissected by headcuts 0.5 to $1 \mathrm{~m}$ high that advanced headward from the stream channel (Fig. 6D).

The longer-term failure of the LW structures was accompanied by a reversion to shallow base flow water depths, and the dominance of centrarchids declined to levels typical of the downstream untreated reach during the fourth year following rehabilitation (Fig. 10). By 3 yr after rehabilitation, streambed carbon levels were not significantly 
different from those measured before rehabilitation ( $p$ 0.05; Stofleth et al. 2004, Shields et al. 2008).

\section{CONCLUSIONS}

Palmer et al. (2005) proposed five criteria with which to assess the success of a stream ecosystem restoration project: (1) the design should be based on a specified guiding image of a more dynamic, healthy river that could exist at the site; (2) the ecological condition must be measurably improved; (3) only minimal follow-up maintenance should be needed, i.e., the project should be self-sustaining; (4) no lasting harm should be inflicted on the ecosystem during construction; and (5) both pre and post assessment must be completed and the data made available to the public. Our project met all of these conditions except for the third one. The restoration of a self-perpetuating, functional stream ecosystem on a trajectory toward the reference condition did not occur at Little Topashaw Creek. The addition of large wood (LW) structures produced temporary improvements in physical habitat quality. Fish community responses were muted, but were consistent with findings by others who noted the importance of LW as cover for centrarchids (Angermeier and Karr 1984, Johnson et al. 1988). However, only traces of the LW structures and willow plantings remained after $5 \mathrm{yr}$. Switchgrass plantings resulted in dense cover on gully walls, but fresh headcuts migrated headward through the planted gully bottoms. The success of LW structures in an unstable channel such as the one that we studied is dependent on rapid plant colonization of sediment deposits. Without vegetation to hold the sediments in place, the sediments will be re-eroded as the LW structures gradually decay and disintegrate. Clearly, the successful use of plant materials for stream corridor habitat rehabilitation is limited by geomorphic processes that act at the landscape scale. In retrospect, the dynamic instability of this site made it a poor candidate for rehabilitation, particularly using live and dead vegetation. Aquatic habitats have been successfully rehabilitated with results that persisted for $>10 \mathrm{yr}$ at other places in this region (Shields et al. 2007), but only with large amounts of stone, steel, and concrete, which are costly and unnatural elements in these systems. Greater success may have been achieved in this project if the LW structure anchoring systems had been more robust and if instream practices had been complemented by measures to address flashy streamflow such as the restoration of floodplain retention, reductions in channel depth, or the construction of upstream reservoirs.

Responses to this article can be read online at: http://www.ecologyandsociety.org/voll3/iss2/art54/responses/

\section{Acknowledgments:}

This project was made possible by the cooperation of landowners Michael Knight, Joe Edmondson, and Lou Ella Callahan. Construction of the Little Topashaw Creek Stream Corridor Rehabilitation Project was funded by the Demonstration Erosion Control Project, which was managed by the Vicksburg District of the U.S. Army Corps of Engineers. Technical reviews by Peter Smiley, Matt Kondolf, and Martin Doyle are gratefully acknowledged.

\section{LITERATURE CITED}

Adams, F. A. 2000. Little Topashaw Creek stream corridor rehabilitation, Chickasaw County, Mississippi. Unpublished geological report to the United States Department of Agriculture Agricultural Research Service, Washington, D.C., USA. Available online at: http://ars.usda.gov/SP2U serFiles/Place/64080515/Topashaw/geologic report. pdf.

Adams, S. B., M. L. Warren, and W. Haag. 2004. Spatial and temporal patterns in fish assemblages of upper coastal plain streams, Mississippi, USA. Hydrobiologia 528(1-3):45-61.

Angermeier, P. L., and J. R. Karr. 1984. Relationships between woody debris and fish habitat in a small warmwater stream. Transactions of the American Fisheries Society 113(6):716-726.

Baker, D. B., R. P. Richards, T. T. Loftus, and J. W. Kramer. 2004. A new flashiness index: characteristics and applications to Midwestern rivers and streams. Journal of the American Water Resources Association 40(2):503-522.

Casagli, N., M. Rinaldi, A. Gargini, and A. Curini. 1999. Pore water pressure and streambank 
stability: results from a monitoring site on the Sieve River, Italy. Earth Surface Processes and Landforms 24(12):1095-1114.

Chu-Agor, M. L., G. V. Wilson, and G. A. Fox. 2008. Numerical modeling of bank instability by seepage erosion undercutting of layered streambanks. Journal of Hydrologic Engineering in press.

Cooper, C. M., S. Testa III, and F. D. Shields, Jr. 2004. Rehabilitation of a severely damaged stream channel with large woody debris structures: macroinvertebrate community response. Bulletin of the North American Benthological Society 21 (1):360.

Dabney, S., F. D. Shields, Jr., D. Temple, A. Collison, and A. Simon. 2002. Layout and establishment of grass hedges for gully control. Pages 464-470 in Proceedings of the 12th International Soil Conservation Organization Conference (Beijing, 2002). Tsinghua University Press, Beijing, China. Available online at: http://w ww.ars.usda.gov/SP2UserFiles/Place/64080515/Topashaw/ layout establishment hedges.pdf.

Dabney, S. M., F. D. Shields, Jr., D. M. Temple, and E. J. Langendoen. 2004. Erosion processes in gullies modified by establishing grass hedges. Transactions of the American Society of Agricultural and Biological Engineers 47 (5):1561-1571.

Darby, S. E., and A. Simon, editors. 1999. Incised river channels: processes, forms, engineering, and management. Wiley, Chichester, UK.

Davis, S. 1999. Within-channel vegetation survey: Little Topashaw Creek stream corridor rehabilitation project. Unpublished report to the United States Department of Agriculture Agricultural Research Service, Washington, D.C., USA. Available online at: http://ars.usda.gov/SP2UserFiles/Place/64080515/ Topashaw/little topashaw.pdf.

Downs, P. W., and A. Simon. 2001. Fluvial geomorphological analysis of the recruitment of large woody debris in the Yalobusha River network, central Mississippi, USA. Geomorphology $\mathbf{3 7}$ (1-2):65-91.

Doyle, M. W., and F. D. Shields, Jr. 1998. Perturbations of stage hydrographs caused by channelization and incision. Pages 736-741 in S. R.
Abt, J. Young-Pezeshk, and C. C. Watson, editors. Water resources engineering '98: proceedings of the International Water Resources Engineering Conference. American Society of Civil Engineers, Reston, Virginia, USA.

Drake, L., and R. Langel. 1998. Deep-planting willow cuttings via water jetting. In D. F. Hayes, editor. Engineering approaches to ecosystem restoration: proceedings of the 1998 Wetlands Engineering and River Restoration Conference (Colorado, 1998). Published on CD-ROM by the American Society of Civil Engineers, Reston, Virginia, USA.

Fox, G. A., M. L. Chu-Agor, and G. V. Wilson. 2007a. Erosion of noncohesive sediment by groundwater seepage: lysimeter experiments and modeling. Soil Science Society of America Journal 71:1822-1830.

Fox, G. A., G. V. Wilson, R. K. Periketi, and R. F. Cullum. 2006. Sediment transport model for seepage erosion of streambank sediment. Journal of Hydrologic Engineering 11(6):603-611.

Fox, G. A., G. V. Wilson, A. Simon, E. J. Langendoen, O. Akay, and J. W. Fuchs. 2007 b. Measuring streambank erosion due to ground water seepage: correlation to bank pore water pressure, precipitation and stream stage. Earth Surface Processes and Landforms 32(10):1558-1573.

Hanson, G. J., and A. Simon. 2001. Erodibility of cohesive streambeds in the loess area of the midwestern USA. Hydrological Processes $\mathbf{1 5}$ (1):23-38.

Hobbs, R. J. 2005. The future of Restoration Ecology: challenges and opportunities. Restoration Ecology 13(2):239-241.

Johnson, D. L., R. A. Beaumier, and W. E. Lynch, Jr. 1988. Selection of habitat structure interstice size by bluegills and largemouth bass in ponds. Transactions of the American Fisheries Society 117 (2):171-179.

Li, S., L. T. Martin, S. R. Pezeshki, and F. D. Shields, Jr. 2005. Responses of black willow (Salix nigra) cuttings to herbivory and flooding. Acta Oecologica 28(2):173-180.

Lizotte, Jr., R. E., M. T. Moore, and C. M. Cooper. 
2006. Little Topashaw Creek-implications of nutrient total maximum daily load (TMDL) criteria for Little Topashaw Creek. Unpublished report to the United States Department of Agriculture Agricultural Research Service, Washington, D.C., USA. Available online at: http://ars.usda.gov/Resea rch/docs.htm?docid=5598.

Martin, L. T., S. R. Pezeshki, and F. D. Shields, Jr. 2004. High oxygen level in a soaking treatment improves early root and shoot development of black willow cuttings. Scientific World 2004(4):899-907.

Martin, L. T., S. R. Pezeshki, and F. D. Shields, Jr. 2005. Soaking treatment increases survival of black willow posts in a large-scale field study. Ecological Restoration 23(2):95-98.

McMahon, T. E., and J. W. Terrell. 1982. Habitat suitability index models: channel catfish. Report FWS/OBS-82/10/2. United States Department Fish and Wildlife Service, Washington, D.C., USA.

Palmer, M., J. D. Allan, J. Meyer, and E. S. Bernhardt. 2007. River restoration in the twentyfirst century: data and experiential knowledge to inform future efforts. Restoration Ecology 15 (3):472-481.

Palmer, M. A., E. S. Bernhardt, J. D. Allan, P. S. Lake, G. Alexander, S. Brooks, J. Carr, S. Clayton, C. N. Dahm, J. Follstad Shah, D. L. Galat, S. G. Loss, P. Goodwin, D. D. Hart, B. Hassett, R. Jenkinson, G. M. Kondolf, R. Lave, J. L. Meyer, T. K. O'Donnell, L. Pagano, and E. Sudduth. 2005. Standards for ecologically successful river restoration. Journal of Applied Ecology 42(2):208-217.

Pezeshki, S. R., S. Li, F. D. Shields, Jr., and L. T. Martin. 2007. Factors governing survival of black willow (Salix nigra) cuttings in a streambank restoration project. Ecological Engineering 29 (1):56-65.

Richter, B. D., J. V. Baumgartner, D. P. Braun, and J. Powell. 1998. A spatial assessment of hydrologic alteration within a river network. Regulated Rivers: Research and Management 14 (4):329-340.

Ries III, K. G., and M. Y. Crouse. 2002. The national flood frequency program, version 3.0: a computer program for estimating magnitude and frequency of floods for ungaged sites, 2002. Report 02-4168. United States Geological Survey, Reston, Virginia, USA.

Rinaldi, M., N. Casagli, S. Dapporto, and A. Gargini. 2004. Monitoring and modelling of pore water pressure changes and riverbank stability during flow events. Earth Surface Processes and Landforms 29(2):237-254.

Schaff, S. D., S. R. Pezeshki, and F. D. Shields, Jr. 2002. Effects of pre-planting soaking on growth and survival of black willow cuttings. Restoration Ecology 10(2):267-274.

Schlosser, I. J. 1987. A conceptual framework for fish communities in small warmwater streams. Pages 17-23 in W. J. Matthews and D. C. Heins, editors. Community and evolutionary ecology of North American stream fishes. University of Oklahoma Press, Norman, Oklahoma, USA.

Shankman, D., and T. B. Pugh. 1992. Discharge response to channelization of a coastal plain stream. Wetlands 12(3):157-162.

Shields, Jr., F. D., and C. M. Cooper. 1994. Riparian wetlands and flood stages. Pages 351-355 in G. V. Controneo and R. R. Rumer, editors. Hydraulic engineering (1994): proceedings of the 1994 conference (Buffalo, 1994). American Society of Civil Engineers, Reston, Virginia, USA.

Shields, Jr., F. D., S. M. Dabney, E. J. Langendoen, and D. M. Temple. 2005. Control of gully erosion using stiff grasses. International Journal of Sediment Research 20(4):319-332.

Shields, Jr., F. D., S. S. Knight, and C. M. Cooper. 1994. Effects of channel incision on base flow stream habitats and fishes. Environmental Management. 18(1):43-57.

Shields, Jr., F. D., S. S. Knight, and C. M. Cooper. 1998. Rehabilitation of aquatic habitats in warmwater streams damaged by channel incision in Mississippi. Hydrobiologia 382(1-3):63-86.

Shields, Jr., F. D., S. S. Knight, and C. M. Cooper. 2007. Can warmwater streams be rehabilitated using watershed-scale standard erosion control measures alone? Environmental Management 40 (1):62-79. 
Shields, Jr., F. D., S. S. Knight, N. Morin, and J. Blank. 2003. Response of fishes and aquatic habitats to sand-bed stream restoration using large woody debris. Hydrobiologia 494(1-3):251-257.

Shields, Jr., F. D., S. S. Knight, and J. M. Stofleth. 2006. Large wood addition for aquatic habitat rehabilitation in an incised, sand-bed stream, Little Topashaw Creek, Mississippi. River Research and Applications 22(7):803-817.

Shields, Jr., F. D., S. S. Knight, and J. M. Stofleth. 2008. Stream bed organic carbon and biotic integrity. Aquatic Conservation: Marine and Freshwater Ecosystems 18(5):761-779.

Shields, Jr., F. D., N. Morin, and C. M. Cooper. 2004. Large woody debris structures for sand-bed channels. Journal of Hydraulic Engineering 130 (3):208-217.

Simon, A. 1989. A model of channel response in disturbed alluvial channels. Earth Surface Processes and Landforms 14(1):11-26.

Simon, A., and A. Curini. 1998. Pore pressure and bank stability: the influence of matric suction. Pages 358-363 in S. R. Abt, J. Young-Pezeshk, and C. C. Watson, editors. Water resources engineering '98: proceedings of the International Water Resources Engineering Conference. American Society of Civil Engineers, Reston, Virginia, USA.

Simon, A., A. Curini, S. E. Darby, and E. J. Langendoen. 2000. Bank and near-bank processes in an incised channel. Geomorphology $\mathbf{3 5}$ (3-4):193-217.

Simon, A., and R. E. Thomas. 2002. Processes and forms of an unstable alluvial system with resistant, cohesive streambeds. Earth Surface Processes and Landforms 27(7):699-718.

Smith, Jr., S., C. M. Cooper, R. Lizotte, Jr., and F. D. Shields, Jr. 2006. Storm pesticide concentrations in Little Topashaw Creek, USA. International Journal of Ecology and Environmental Sciences 32(2):173-182. Available online at: http:// ars.usda.gov/SP2UserFiles/Place/64080515/Topashaw/ storm concentrations.pdf.

Society for Ecological Restoration International Science and Policy Working Group. 2004. The SER international primer on ecological restoration.
Version 2. Society for Ecological Restoration International, Tucson, Arizona, USA. Available online at: http://ser.org/pdf/primer3.pdf.

Stofleth, J. M., F. D. Shields, Jr., and G. A. Fox. 2004. Organic carbon concentrations in hyporheic zone sediments: a tool for measuring stream integrity. In G. Sehlke, D. F. Hayes, and D. K. Stevens, editors. Critical transitions in water and environmental resources management: proceedings of the 2004 World Water and Environmental Resources Congress (Salt Lake City, 2004). Published on CD-ROM by the American Society of Civil Engineers, Reston, Virginia, USA.

Stofleth, J. M., F. D. Shields, Jr., and G. A. Fox. 2008. Hyporheic and total transient storage in small, sand-bed streams. Hydrological Processes 22 (12):1885-1894.

Stuber, R. J., G. Gebhart, and O. E. Maughan. 1982. Habitat suitability index models: largemouth bass. Report FWS/OBS-82/10.16. United States Fish and Wildlife Service, Washington, D.C., USA.

Testa III, S., and C. M. Cooper. 2002. Considerations for water resource bioassessments based on aquatic macroinvertebrate communities: Mississippi experiences. P. M. Wilson, editor. Proceedings of the Mississippi Water Resources Conference. Published on CD-ROM by the Mississippi Water Resources Research Institute, Mississippi State University, Starkville, Mississippi, USA. Available online at: http://www.ars.usda.gov/ SP2UserFiles/Place/64080515/Topashaw/ considerations bioassessments.pdf.

USDA. 2006a. Little Topashaw Creek-construction. United States Department of Agriculture Agricultural Research Service, Washington, D.C., USA. [online] URL: http://ars.usda.gov/Research/docs. htm? docid=5643.

USDA. 2006b. Little Topashaw Creek-LWDS failure. United States Department of Agriculture Agricultural Research Service, Washington, D.C., USA. [online] URL: http://ars.usda.gov/Research/docs. htm?docid=5534.

USDA. 2008. Little Topashaw Creek. United States Department of Agriculture Agricultural Research Service. [online] URL: http://ars.usda.gov/Research/ docs.htm?docid=5526. 
Wallerstein, N. P. 2000. Geomorphic evaluation of Little Topashaw Creek: June 2000. Unpublished report to the United States Department of Agriculture Agricultural Research Service, Washington, D.C., USA. Available online at: http://www.ars.usda. gov/SP2UserFiles/Place/64080515/Topashaw/

geomorphic evaluation.pdf.

Webb, P. W., and V. de Buffrénil. 1990. Locomotion in the biology of large aquatic vertebrates. Transactions of the American Fisheries Society 119(4):629-641.

Wilson, G. V., R. K. Periketi, G. A. Fox, S. M. Dabney, F. D. Shields, and R. F. Cullum. 2007. Soil properties controlling seepage erosion contributions to streambank failure. Earth Surface Processes and Landforms 32(3):447-459.

Wu, W., F. D. Shields, Jr., S. J. Bennett, and S. S. Y. Wang. 2005. A depth-averaged two-dimensional model for flow, sediment transport, and bed topography in curved channels with riparian vegetation. Water Resources Research 41(3): W03015. 